\title{
GREASE QUALITY ISSUES ON MIDDLE VOLTAGE SWITCHGEAR: CORROSIVITY, RESISTIVITY, SAFETY AND AGEING
}

\author{
Mohd SAbri Mahmud ${ }^{1 *}$, SAnUri Ishak ${ }^{2}$, Mohd NaJib Razali ${ }^{1}$, Mohd AizUdin \\ ABdUl AZIZ ${ }^{1}$ AND MUSFAFIKRI MUSA ${ }^{1}$ \\ ${ }^{I}$ Faculty of Chemical and Natural Resources Engineering, Universiti Malaysia Pahang, \\ Tun Razak Highway, Gambang, 26300 Kuantan, Pahang, Malaysia. \\ ${ }^{2}$ Tenaga Nasional Berhad Research Sendirian Berhad, No. 1 Research Institute Area, \\ Jalan Ayer Itam, 43000, Kajang, Selangor, Malaysia. \\ *Corresponding author: mohdsabri@ump.edu.my
}

(Received: 22 $2^{\text {nd }}$ Sept 2018; Accepted: $27^{\text {th }}$ April 2019; Published on-line: $1^{\text {st }}$ June 2019)

https://doi.org/10.31436/iiumej.v20i1.995

\begin{abstract}
Grease products recommended by OEM for conventional $11 \mathrm{kV}$ switchgears are generally trusted. Some disadvantages might however exist among them or their supply could be insufficient and lead to use of non-OEM-recommended grease. This paper reports analysis methods to evaluate both types of grease that were recently used in the switchgears at local electrical distribution stations owned by Tenaga Nasional Berhad. Hardened, greenish and severely irritating greases probably caused by incompatible compounding, electrochemical reaction, and hazardous components, respectively, were among common problems faced by workers. Eight physical tests and four chemical tests were conducted on 10 grease samples using thermogravimetry, switchgear rig, gas chromatography and infrared spectroscopy besides other equipment and standard methods. Grease stability, oil bleeding, flammability of grease droplet and dropping point were among the characteristics determined in the analyses. The results reveal copper corrosion, chemical change, instable and inconsistent grease, and toxics in grease, which surprisingly included the OEM-recommended one.
\end{abstract}

ABSTRAK: Produk gris yang disyorkan oleh Pengeluar Peralatan Asal (OEM) bagi gearsuis konvensional $11 \mathrm{kV}$ secara umumnya dipercayai ramai. Kemungkinan terdapat kekurangan pada produk-produk tersebut ataupun bekalan gris mereka yang tidak mencukupi telah mendorong kepada penggunaan gris yang tidak disyorkan oleh OEM. Kaedah analisis kajian ini melaporkan tentang kedua-dua jenis gris yang kebelakangan ini digunakan oleh Tenaga Nasional Berhad pada gear-suis di stesen pencawang elektrik. Gris mengeras, berlumut dan menjengkelkan mungkin disebabkan oleh sebatian bahan yang tidak sesuai, tindak balas elektrokimia dan komponen yang tidak selamat, masing-masing adalah antara masalah yang dihadapi oleh para pekerja. Lapan ujian fizikal dan empat ujian kimia telah dijalankan pada 10 sampel gris menggunakan termogravimetri, pemakai gearsuis, kromatografi gas dan spektroskopi inframerah selain alatan lain dan kaedah-kaedah piawai. Antara ciri-ciri yang dikaji dalam analisis ini adalah kestabilan gris, sifat lelehan minyak, sifat mudah terbakar titisan gris dan takat rendah gris. Hasil kajian mendapati gris ini menyebabkan tembaga terhakis, sifat kimia berubah, sifat gris yang tidak stabil dan mudah berubah, dan juga beracun memberi kejutan kerana pihak OEM tetap mengesyorkan gris jenis ini.

KEYWORDS: switchgear grease; switchgear corrosion; grease analysis; grease corrosivity; grease resistivity; grease safety and ageing 


\section{INTRODUCTION}

Characterization of grease for mechanical bearing components is well developed. Various tests were standardized to check bearing life, friction, fretting and false brinelling, noise, and grease life [1]. The lubricating grease for electrical connection however needs additional testing because the grease will be on the contact surface for a long time facing various room conditions, air humidity, and heat from electricity. The switchgear grease should have heat stability to withstand inconsistent temperature due to electrical resistance, unexpected arcing and friction. It must also be consistent for years and not harden as the switching movement is very seldom and involves high electric potential. The electric potential may initiate undesired electrochemical reaction due to charged or sub-charged components of grease that would lead to corrosion and greenish staining on the switchgear part, as shown in Fig. 1.

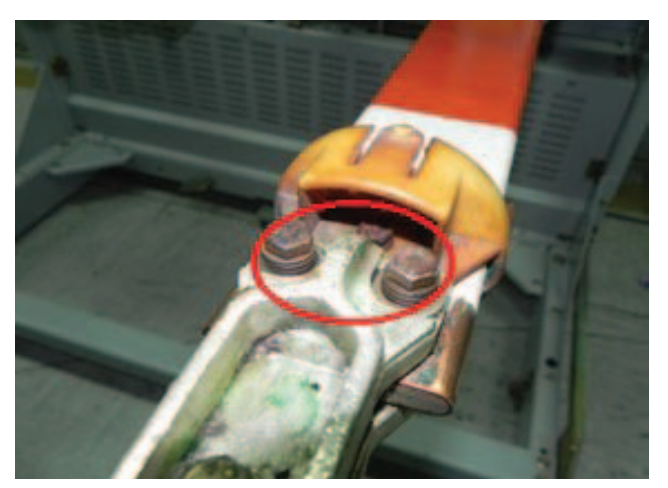

Fig. 1: Corrosion and greenish stain on the switchgear part.

Compounding of a grease is usually confidential. OEM-recommended greases are generally expensive and produced on a specific purpose and equipment. When the technology employed in the equipment becomes obsolete, production of grease may also be reduced or cease. Investigating the content of a grease is normally tedious because it involves derivation of unknown complex chemicals from both solid and liquid phases. The use of analytical equipment for chemical property such as FTIR, gas chromatography and thermogravimetry helps consumers profile the content of both phases and plan for replacement frequency and stocking. Issues of corrosion, safety and health, and lubrication defect necessitate chemical analysis to determine the functional group, chemical species and composition, and elementary composition.

This study employed grease tests that were related to the complaints raised by the personnel of the electric company. Physical property under hot environment, electric resistivity, and chemical property are the focus of the experiments. The temperature was set between $50-110^{\circ} \mathrm{C}$ from the highest temperature of the switchgear $\left(90^{\circ} \mathrm{C}\right)$ in order to accelerate reactions - decomposition, oxidation, reduction, and transformation. Some of the tests were not from any standard methods and all runs were carried out more than once to ascertain the results. The brands of the $11-\mathrm{kV}$ switchgears employed in local power distributors were Electrical Power Engineering (EPE), Schneider, ABB, Tamco, Siemens/Item, and Toshiba. 


\section{MATERIALS AND METHODS}

\subsection{Materials}

Heptane (99\%), $\mathrm{K}_{2} \mathrm{CO}_{3}, \mathrm{Na}_{2} \mathrm{SO}_{4}$, hydrochloride acid reagent (37\%) were supplied by Merck. 10 grease samples were tested. Eight samples were obtained from Tenaga Nasional Berhad Research, of which 3 were OEM-recommended and 5 were non-OEMrecommended for use in their electric power distributors. However, the brands of the greases are confidential and the terms 'OEM' and 'NOEM' denote OEM and non-OEM recommended greases, respectively, which are all followed by numbers. The final 2 samples were non-OEM recommended greases proposed by Universiti Malaysia Pahang and are denoted by Prop and followed by numbers.

\subsection{Thermogravimetric Analysis}

Evaporation of volatile components and decomposition indicate the stability of the grease. The samples were analyzed using a TA Instruments TGA Q500 based on the ASTM E2550 method. The analysis was conducted under inert conditions using nitrogen gas blanketing. A few milligrams of sample were put in a pan and heated under a $10^{\circ} \mathrm{C} / \mathrm{min}$ program from ambient temperature to $800{ }^{\circ} \mathrm{C}$. The TGA analysis under isothermal conditions at $150^{\circ} \mathrm{C}$ was also carried out for 3 hours to estimate the grease ageing. The data was integrated via QNX/Platinum ${ }^{\mathrm{TM}}$ software to generate plots of weight and derivative weight lost versus temperature.

\subsection{0-Day Heating}

As an extension to the thermogravimetric analysis, the stability of the grease samples was further studied by observing their weight lost in an oven from $50{ }^{\circ} \mathrm{C}$ to $150{ }^{\circ} \mathrm{C}$ for 10 days. The samples were also graded by penetration and bleeding tests.

\subsection{Dropping Point and Fire Test}

The first drop of grease liquid at a particular temperature was determined manually following the steps described in ASTM D556 using 2 thermometers, a Pyrex tube, fabricated cups, and an oven. The samples were put on the internal wall of the cup while the thermometer was inserted into a tube inside the same cup without touching the sample. The other thermometer was put outside the cup but inside the oven. The temperature of the oven was increased at $2{ }^{\circ} \mathrm{C}$ intervals. Ten minutes were allocated to allow the samples to reach the desired temperature. As the grease dropped, the experiment was stopped and one third of the temperature difference between tube and oven was calculated as the variance of the dropping point. The test was repeated three times. The droplet was further tested for flammability using a Bunsen burner and a glass rod at ambient temperature. After 5 seconds of being in the flame, the presence (or lack) of a fire or flash was observed and recorded.

\subsection{Oil Bleeding Test}

AN SKF Grease Test Kit was employed to analyze oil bleeding of the samples as per ASTM D4950. A quantity of $0.5 \mathrm{~g}$ of grease was put on a piece of blotter paper. After two hours at $60{ }^{\circ} \mathrm{C}$, oil that was released from the sample appeared as stain on the paper. The area of the stain was measured and the values were then interpreted according to NLGI standard. Fig. 2 illustrates the test.

\subsection{Penetration}

The consistency of the grease was measured using the cone penetration test (ASTM D217). The cone was dropped into the grease by a Koehler K19500 Penetration Test and 
the depth of penetration was measured in tenths of a millimeter. The depth of the penetration indicated how thin the grease consistency was, as per NLGI classification.

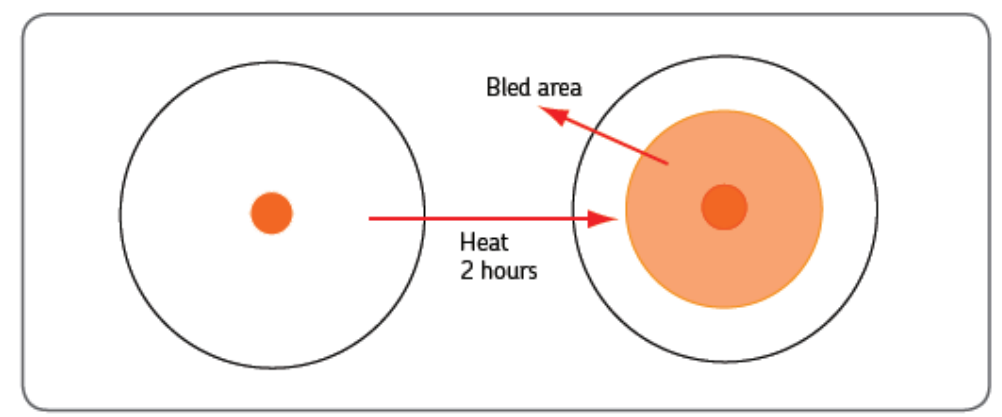

Fig. 2: Bleeding test.

\subsection{Contact Resistance}

Resistance of switchgear contact (Ohms or Siemens per meter) was tested by measuring the resistance of electrical connections. This test was specifically to evaluate electrical connections made in the presence of the grease samples by checking contact resistance. Two sensing cables (using the same polarities to existing cables) on two sides of the contacts were connected to the targeted object as close as possible, as illustrated in Fig. 3.

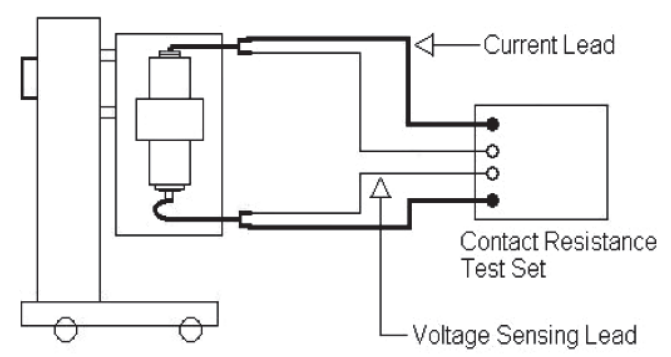

Fig. 3: Connection diagram for circuit breaker (close position).

The variation of no more than $20 \%$ from the result for a fresh sample, compared using similar connections, is acceptable based on measurement of the resistance of the circuit/main circuit [2]. The resistivity of the grease was tested by applying it to the $11 \mathrm{kV}$ contacting arm using fresh samples, and those samples were heated at $150{ }^{\circ} \mathrm{C}$ for 24 hours. The difference of contact resistance without grease, fresh samples, and prolonged-heated samples were compared.

\subsection{Corrosivity}

Greenish grease indicates a possibility of copper corrosion on the switchgear arms. A clean copper strip was coated with each sample and was kept in the oven and furnace under $100{ }^{\circ} \mathrm{C}, 150{ }^{\circ} \mathrm{C}$, and $200{ }^{\circ} \mathrm{C}$ for several days following the ASTM D4048 method. The resulting colors of the strips were interpreted according to the standard codes by a same person at all times, in to avoid bias.

\subsection{Chemical Analysis}

Functional groups were analyzed by using a Nicolet iS5 FTIR Spectrometer equipped with iD7 ATR, which was supplied by Thermo Fischer Scientific, USA. Alkane, carbonyl group, and hydroxyl group are among the common functional groups that usually exist in the grease. The sample was scanned from $4000 \mathrm{~cm}^{-1}$ to $600 \mathrm{~cm}^{-1}$ wavelength. 
Chemical species in the grease were analyzed using gas chromatography (GC) equipped with a mass spectrometer detector (GC-MS). In chromatographic analysis, lubricant and additive organic liquid were dissolved using heptane for safety reasons since its solubility is comparable to hexane. The procedure presented by Synder et al. [3] was therefore referred with some modification. Five grams of grease was stirred in a beaker with $100-\mathrm{ml}$ of heptane for $20 \mathrm{~min}$. The polar compound of soap, salt, and ionic complex that settled at the bottom of the beaker was next separated using filter paper, glassware, and a vacuum pump. The cake of undissolved material was peeled away using a spatula when it was dry.

One gram of the cake was mixed with $100-\mathrm{ml}$ methanol and $1 \mathrm{ml}$ of concentrated $\mathrm{HCl}$ at $60{ }^{\circ} \mathrm{C}$ in a flask was agitated on a hot plate stirrer for $20 \mathrm{~min}$ for derivatization of methyl esters. Next, the substrate was washed with a $200-\mathrm{ml}$ beaker of water to remove remaining methanol and the acid at room temperature in a separating funnel at least thrice. One hundred $\mathrm{ml}$ of heptane was finally added to extract methyl esters. The heptane-enriched layer was then taken using a pipette and transferred to a test tube containing $\mathrm{K}_{2} \mathrm{CO}_{3}$ and $\mathrm{Na}_{2} \mathrm{SO}_{4}$. The heptane solution from extraction of the lubricant and methyl esters derived from thickeners were both analyzed in an Agilent GC-MS equipped with an Agilent DB-1 dimethylpolysiloxane column using helium as the carrier gas. The injections of samples were at $250{ }^{\circ} \mathrm{C}$ and the detector temperature was set at $280{ }^{\circ} \mathrm{C}$. The oven was under a program of $65^{\circ} \mathrm{C}$ for $3 \mathrm{~min}$, subsequent ramping of temperature of $20{ }^{\circ} \mathrm{C} / \mathrm{min}$ and a final condition of $250{ }^{\circ} \mathrm{C}$ for $5 \mathrm{~min}$ were set. The components were identified using the spectrometer library of elements.

Elemental analysis was also conducted to check the existence of metals in the samples. An Agilent ICP-MS 7500a was used to determine common salt and metal-based additives such as lithium, aluminum, potassium, calcium, chromium, strontium and metals that were lower electropositive than copper, that were added to grease such as molybdenum and silver. The rate of plasma was $15 \mathrm{ml} / \mathrm{min}$. The flow rates of auxiliary, carrier gas, and sample uptake were $0.8 \mathrm{ml} / \mathrm{min}$ under auto detection mode. Elements inside the samples were all derived using nitric acid solution.

\section{RESULTS AND DISCUSSION}

\subsection{Corrosive and Safety}

Corrosion of the samples of copper strip coated with grease was performed at three oven temperatures at different periods, resulting in various colors of stain. Although the effect of friction due to the corroded surface of copper-made arms of switchgear is minor, the corrosion roughened the contact surface and produced an uneven copper oxide layer that increased the resistance to electric current [4]. Table 1 shows the colors coded as per ASTM standards and molybdenum element. NOEM3 and NOEM4 did not oxidize copper. Four samples corroded resulting in totally black copper strips i.e. OEM2, NOEM2, NOEM5 and Prop1 after 3 and 2 days in $150{ }^{\circ} \mathrm{C}$ and $200{ }^{\circ} \mathrm{C}$ oven, respectively, while other greases only caused tarnishing. NOEM2 did not corrode at $100{ }^{\circ} \mathrm{C}$ for 6 days. This result indicates that, even though the grease was recommended by OEM, the metal compound (cation) existing in the grease was less electropositive than copper metal and would lead to oxidation of copper at high temperature. This finding is similar to what El-Daly and Turky [5] reported when two greases of unknown compounds were analyzed using the copper strip test. ICPMS analysis further confirmed the presence of low electropositive metal of molybdenum in 4 corrosive grease samples, i.e. OEM1, OEM2, NOEM4 and Prop1 as shown in Table 3. Presence of molybdenum may corrode and thus resist switch operations [6]. The other two 
corrosive grease samples, NOEM2 and NOEM5, did not have molybdenum result by ICPMS.

Table 1: Results of corrosion, dropping point and penetration

\begin{tabular}{|c|c|c|c|c|c|c|c|c|}
\hline \multirow[t]{2}{*}{ Samples } & \multicolumn{3}{|c|}{$\begin{array}{l}\text { ASTM Copper Strip } \\
\text { Corrosion Standard* }\end{array}$} & \multirow[t]{2}{*}{$\begin{array}{c}\text { Mo } \\
\text { (bpm) }\end{array}$} & \multirow[t]{2}{*}{$\begin{array}{l}\text { Dropping } \\
\text { Point }\left({ }^{\circ} \mathrm{C}\right)\end{array}$} & \multirow[t]{2}{*}{ Fire test } & \multicolumn{2}{|c|}{$\begin{array}{c}\text { Penetration } \\
\text { (NLGI) }\end{array}$} \\
\hline & $\begin{array}{c}100^{\circ} \mathrm{C} \\
\text { in } 6 \\
\text { days }\end{array}$ & $\begin{array}{l}150^{\circ} \mathrm{C} \\
\text { in } 3 \\
\text { days }\end{array}$ & $\begin{array}{c}200^{\circ} \mathrm{C} \\
\text { in } 2 \\
\text { days }\end{array}$ & & & & Fresh & $\begin{array}{c}\text { Heated } \\
\text { in } 10 \\
\text { days }\end{array}$ \\
\hline OEM1 & 1a & $1 \mathrm{~b}$ & $3 a$ & 2 & 295 & Not ignited & 3 & 3 \\
\hline OEM2 & $4 c$ & $4 c$ & $4 c$ & 1506 & 198.8 & $\begin{array}{l}\text { Ignited and } \\
\text { flashed }\end{array}$ & 2 & 3 \\
\hline OEM3 & $2 \mathrm{~d}$ & $2 d$ & $3 b$ & - & 258.3 & Not ignited & 1 & 1 \\
\hline NOEM1 & $1 \mathrm{a}$ & $3 b$ & $3 b$ & - & 207.1 & Not ignited & 2 & 2 \\
\hline NOEM2 & $1 b$ & $4 \mathrm{c}$ & $4 c$ & - & $>344$ & Not ignited & 2 & 2 \\
\hline NOEM3 & $1 \mathrm{a}$ & $1 \mathrm{a}$ & $2 c$ & - & $>344$ & $\begin{array}{l}\text { Ignited and } \\
\text { flame } \\
\text { sustained }\end{array}$ & 3 & 3 \\
\hline NOEM4 & $1 \mathrm{a}$ & $1 \mathrm{a}$ & $2 \mathrm{c}$ & - & 137.1 & Not ignited & 00 & 00 \\
\hline NOEM5 & $4 c$ & $4 c$ & $4 c$ & - & 327.3 & Not ignited & 1 & 1 \\
\hline Prop1 & $4 c$ & $4 d$ & $4 d$ & 2150 & 150 & Not ignited & 2 & 3 \\
\hline Prop2 & $1 \mathrm{a}$ & $3 b$ & $3 c$ & - & 230 & Not ignited & 2 & 2 \\
\hline
\end{tabular}

* 1a-1b: slight tarnish, 2a-2e: moderate tarnish, 3a-3b: dark tarnish and 4a-4c: corrosion

Table 1 also shows the other results. Dropping point analysis reveals that NOEM4 liquefied below $150{ }^{\circ} \mathrm{C}$. A droplet might contain flammable liquid that could cause electrical arcing and fire. Painstaking testing was subsequently conducted to determine flammability of the droplet (mixing of lubricant and other compounding fluid from the dropped grease) shows that OEM 2 and NOEM3 could catch fire at room temperature. Although they were physically buttery and medium solid as indicated by NLGI grade, liquid dropped from these grease samples at high temperature may cause fire in the switchboard and can therefore be considered as Class B fires that require use of chemicals to extinguish the fire [7].

Chemical identity of grease components were determined from the FTIR results within $70 \%$ sensitivity. As can be seen in Fig. 4, all of them contained alkane where transmittance percentage of the peaks stretching of $\mathrm{CH}_{2}$ and $\mathrm{CH}_{3}$ were within $725-720 \mathrm{~cm}^{-1}, 3000-2840$ $\mathrm{cm}^{-1}$ and $1450-1375 \mathrm{~cm}^{-1}$ wavelength, which were probably attributed to lubricant and aliphatic chain of soaps [8]. $\mathrm{C}=\mathrm{O}$ and $\mathrm{C}=\mathrm{C}$ were present in OEM3, NOEM1 and Prop1, stretching from 1650 to $1600 \mathrm{~cm}^{-1}$. Other functional groups detected in the spectra were integrated by the OMNIC software to propose species of chemicals for each grease as listed in Table 2. Similarly, the samples heated at $150{ }^{\circ} \mathrm{C}$ for 10 days were analyzed and were compared. Thickening the bundle of peaks

Alumino silicate, kaolin clays, and aliphatic compounds bound with sulfoxide, halogen, acrolein aldehydes, phosphates, and vinyl olefins were found. 3 samples, i.e. NOEM2, NOEM3 and Prop1, changed after 10 days treatment of $10{ }^{\circ} \mathrm{C} /$ day heating and were probably involved with the reaction. This deteriorated the consistency of the grease. Although other grease samples did not have the functional groups, their color became dark and black, as particularly shown by the best grease in Fig. 5, indicating that there was change of chemical property in the same functional group. This results similarly reported by Jiabao et al. [9] where physical property of their tested greases changed without considerable change in the chemical property, was analyzed using FTIR. 

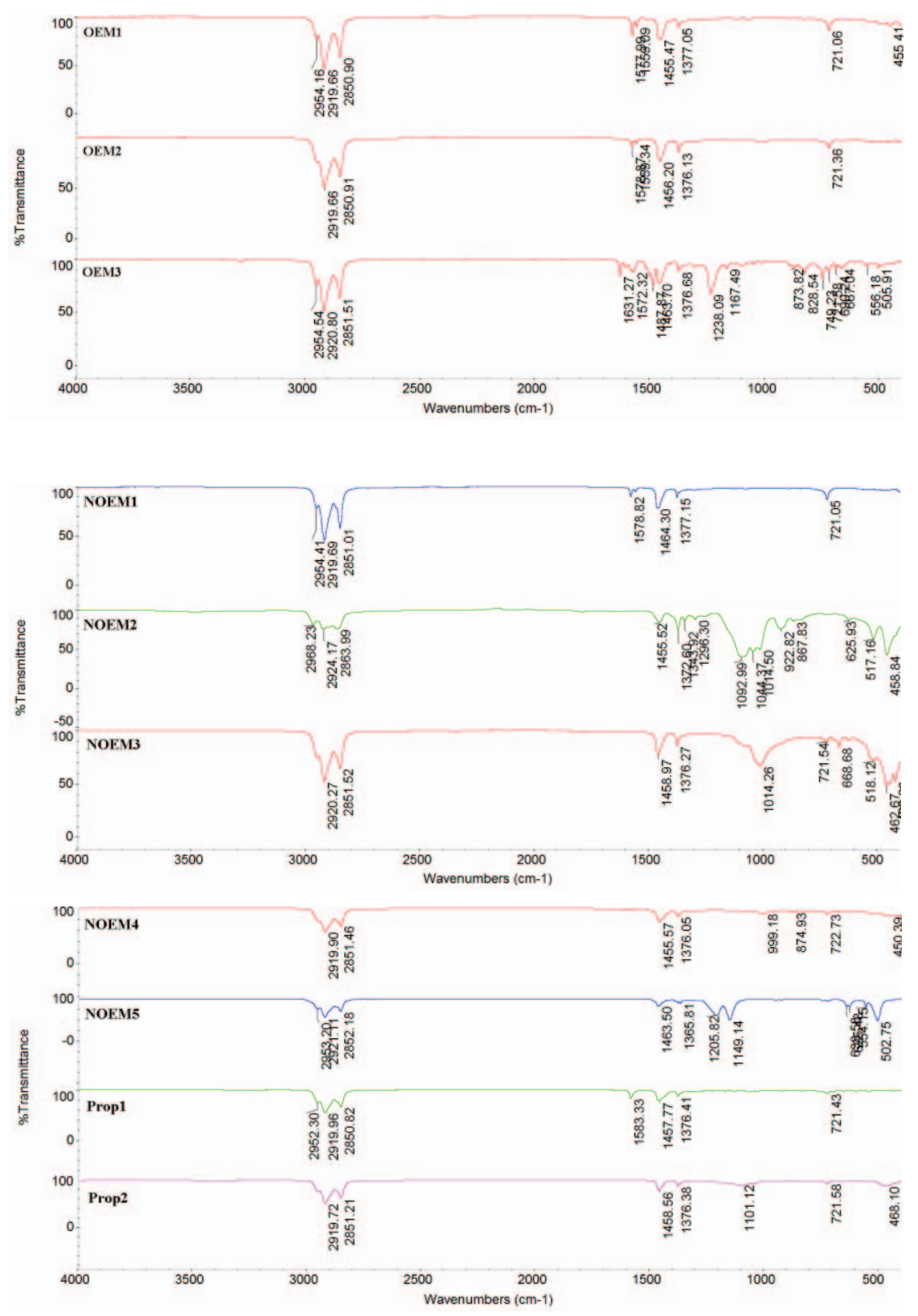

Fig. 4: FTIR results for all grease samples.

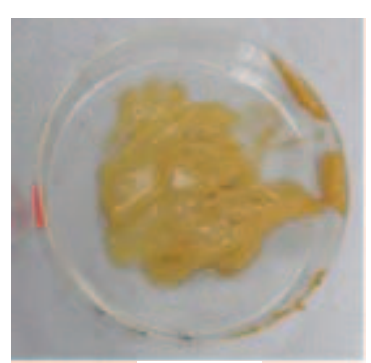

(a)

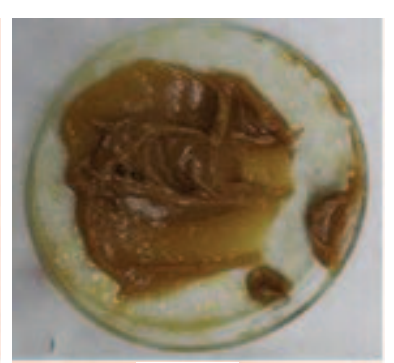

(b)

Fig. 5: OEM1 after 10 days at (a) ambient temperature - no change, and (b) $150{ }^{\circ} \mathrm{C}$ after elevated $10{ }^{\circ} \mathrm{C} /$ day for 10 days - dark. 
Table 2: Results of predicted group of chemicals and comparison of FTIR spectra between temperature conditions

\begin{tabular}{|c|c|c|c|}
\hline Samples & Ambient Temperature & Treated & Remark \\
\hline OEM1 & Aliphatic Hydrocarbons & Aliphatic Hydrocarbons & No change \\
\hline OEM2 & Aliphatic Hydrocarbons & Aliphatic Hydrocarbons & No change \\
\hline OEM3 & $\begin{array}{c}\text { Trans olefins } \\
\text { Aliphatic Hydrocarbons }\end{array}$ & $\begin{array}{c}\text { Trans olefins } \\
\text { Aliphatic Hydrocarbons }\end{array}$ & No change \\
\hline NOEM1 & Aliphatic Hydrocarbons & Aliphatic Hydrocarbons & No change \\
\hline NOEM2 & $\begin{array}{c}\text { Aliphatic Hydrocarbons, } \\
\text { Aliphatic Alpha Halogen } \\
\text { Ketones, Kaolin Clays/ } \\
\text { Alumino Silicates }\end{array}$ & $\begin{array}{l}\text { Aliphatic Hydrocarbons, } \\
\text { Aliphatic Acrolein Aldehydes } \\
\text { Inorganic Phosphates }\end{array}$ & Changed \\
\hline NOEM3 & $\begin{array}{l}\text { Aliphatic Hydrocarbons, } \\
\text { Aliphatic Sulfoxides }\end{array}$ & $\begin{array}{l}\text { Aliphatic Hydrocarbons, } \\
\text { Aliphatic Primary Amines }\end{array}$ & Changed \\
\hline NOEM4 & $\begin{array}{l}\text { Aliphatic Hydrocarbons } \\
\text { Terminal Vinyl Olefins }\end{array}$ & $\begin{array}{l}\text { Aliphatic Hydrocarbons } \\
\text { Terminal Vinyl Olefins }\end{array}$ & No change \\
\hline NOEM5 & $\begin{array}{l}\text { Aliphatic Hydrocarbons } \\
\text { Perluorinated Alkanes }\end{array}$ & $\begin{array}{l}\text { Aliphatic Hydrocarbons, } \\
\text { Perfluorinated Alkanes }\end{array}$ & No change \\
\hline Prop1 & Aliphatic Hydrocarbons & $\begin{array}{l}\text { Perfluorinated Alkanes, } \\
\text { Aliphatic Carboxylic Acid Salts }\end{array}$ & Changed \\
\hline Prop2 & $\begin{array}{l}\text { Aliphatic Hydrocarbons } \\
\text { Kaolin Clays/ Alumino } \\
\text { Silicate }\end{array}$ & $\begin{array}{c}\text { Aliphatic Hydrocarbons } \\
\text { Kaolin Clays/ Alumino Silicate }\end{array}$ & No change \\
\hline
\end{tabular}

Lubricant and FAME derived from thickeners and additive were analyzed in the GCMS. Colloidal aqueous layer was present during extraction using heptane in the sample preparation of NOEM2, NOEM3 and Prop1, which was probably attributed to emulsion of short-chain methyl esters that dissolved in water. GC-MS analysis results revealed possible chemical compounds. Among the generic compound of lubricants such as paraffin oils and mineral oils [10], and specific chemical names for aliphatic hydrocarbon, alkane, etc. mentioned in the FTIR analysis, hazardous chemicals were also identified by comparing with components in a mass spectrometry library. All grease contained fatty acid alkyl ester where the alkyl probably came from methyl, ethyl, or butyl groups. Bis(4octylphenyl)amine, that may cause irritation, was detected at $23 \%$ and $24 \%$ with detection quality (Qual) greater than $90 \%$ in OEM1 and OEM3. Butylated hydroxytoluene, that is carcinogenic if swallowed or introduced through wounds, was found with 98\% Qual in OEM3.

ICP-MS is very sensitive and could measure elements below $10 \mathrm{ppm}$, as shown in Table 3 [11]. Metal from contamination of abrasion or corrosion of the contact surface or container can be detected by ICP-MS better than ICP-OES and ICP-AAS. OEM1, OEM2 and NOEM1 were clearly lithium-based greases. Argentum, which normally exists in metal form, was detected in OEM2 and Prop2. Aluminum was detected in all grease while calcium was not detected in OEM1 and NOEM3. Aluminum and calcium are normally present in salt or complex form and mixture of thickeners will be incompatible if both compounds exist abundantly in the same grease [6] as evidenced by separate liquid in NOEM4 and Prop2 containers. Strontium was found in all grease whereas kalium was found the same except in NOEM3. No barium was found in any grease samples. 
Table 3: Concentration of argentum and other elements in ppm in grease samples

\begin{tabular}{cccccccccc}
\hline Grease & $\mathbf{L i}$ & $\mathbf{A l}$ & $\mathbf{K}$ & $\mathbf{C a}$ & $\mathbf{C r}$ & $\mathbf{S r}$ & $\mathbf{A g}$ & $\mathbf{B a}$ & $\mathbf{M o}$ \\
\hline OEM1 & 1321.5 & 23 & 25 & - & - & 32 & 2 & - & 2 \\
OEM2 & 1322.1 & 17 & 22 & 1.3 & - & 3838 & 1506 & - & 1506 \\
OEM3 & 0.9 & 510 & 19 & 4 & - & 133 & - & - & - \\
NOEM1 & 488.7 & 30 & 23 & 1 & - & 37 & - & - & - \\
NOEM2 & 0.7 & 19 & 24 & 9 & - & 4587 & - & - & - \\
NOEM3 & 0.2 & 7879 & - & - & - & 80 & - & - & - \\
NOEM4 & 1.0 & 2574 & 45 & 5450 & - & 70000 & - & - & 154 \\
NOEM5 & 0.2 & 1525 & 25 & 1 & - & 77 & - & - & - \\
Prop1 & 1.2 & 20 & 26 & 5 & - & 2327 & 2150 & - & 2150 \\
Prop2 & 1.0 & 969 & 22 & 1866 & - & 1202 & - & - & - \\
\hline
\end{tabular}

\subsection{Resistance of Grease}

Resistance of real switchgear under $11-\mathrm{kV}$ potential was compared between fresh and heated grease $\left(150{ }^{\circ} \mathrm{C}\right.$ for 24 hours) using different contact switch arms. Blank tests were also carried out for each grease before the grease was applied, to get initial resistance. All analyses were repeated at least twice and the average values were recorded. All grease samples showed changes in resistance. As can be seen in Table 4, the highest difference in resistance (in $\mu \Omega / \mathrm{m}$ ) between blank and fresh grease was $16 \%$ in OEM1, which is still below the $20 \%$ limit. In the other comparison between fresh and heated samples, the resistance of OEM3-applied switchgear increased 14\%, which was worse than the non-OEM recommended greases. Although these values were lower than $20 \%$, in the long term, the OEM3 might increase in resistance and cause switchgear heating [6]. Therefore the greases that showed dropping trends are preferable in the aspect of conductivity.

Table 4: Contact resistance result

\begin{tabular}{lllllll}
\hline Grease & \multicolumn{5}{c}{ Contact Resistance - measured on 1 contact to 1 joint } \\
\cline { 2 - 7 } & $\begin{array}{l}\text { Without } \\
\text { grease } \\
(\mu \Omega)\end{array}$ & $\begin{array}{l}\text { Fresh } \\
\text { grease } \\
(\mu \Omega)\end{array}$ & $\begin{array}{l}\% \\
\text { difference }\end{array}$ & $\begin{array}{l}\text { Without } \\
\text { grease } \\
(\mu \Omega)\end{array}$ & $\begin{array}{l}\text { heated } \\
\text { grease } \\
(\mu \Omega)\end{array}$ & $\begin{array}{l}\% \\
\text { difference }\end{array}$ \\
\hline OEM1 & 77.7 & 90.3 & 16 & 58.3 & 64.5 & 11 \\
OEM2 & 82.5 & 93.43 & 13 & 62.6 & 62.0 & -1 \\
OEM3 & 70.7 & 70.2 & -1 & 80.7 & 91.2 & 13 \\
NOEM1 & 73.1 & 85.8 & 17 & 80.9 & 84.6 & 5 \\
NOEM2 & 73.4 & 78.2 & 7 & 87.6 & 75.3 & -14 \\
NOEM3 & 72.6 & 71.3 & -2 & 60.5 & 56.8 & -6 \\
NOEM4 & 83.5 & 87.7 & 5 & 69.2 & 59.2 & -14 \\
NOEM5 & 75,2 & 69.3 & -8 & 60.4 & 71.2 & 18 \\
Prop1 & 72.1 & 78.1 & 8 & 71.7 & 63.6 & -11 \\
Prop2 & 70.4 & 76.7 & 9 & 67.5 & 74.4 & 10 \\
\hline
\end{tabular}

\subsection{Ageing of Grease}

Ageing of the grease samples was determined based on thermogravimetric analysis, stability, oil bleeding, and dropping point. Switchgear movement does not involve high temperature like mechanical devices. Nonetheless, heat that could degrade the grease might be produced from electrical resistance while switching and also because of hotspots [6]. The 
highest temperature that local switchgears could reach was reportedly $90{ }^{\circ} \mathrm{C}$ without considering the hotspot due to arcing [12]. Thus, decomposition of grease is possible when this condition prolonged for several months before the grease is replaced.

The results of the thermogravimetric study under inert conditions, shown in Fig. 6, for all grease samples demonstrate decomposition profiles of the samples in elevated temperature. Generally, all greases except Prop1 started decomposition at about $200{ }^{\circ} \mathrm{C}$. Fig. 6(a) shows the profiles for 3 OEM-recommended greases. The single drop that occurred until $10-1 \mathrm{wt} \%$ indicates homogeneity between lubricant and other grease components in forming collective vaporization and decomposition. Fig. 6(b) and 6(c) illustrate the decomposition profile for 5 non-OEM-recommended greases. Only NOEM1 and NOEM2 had the single drop. NOEM2, NOEM3 and NOEM4 had more than $15 \mathrm{wt} \%$ non-composing materials, probably thickener and additive made from metal-based compounds, as previously evidenced in the ICP-MS data. The results for Prop1 and Prop2 in Fig. 6(d) show that Prop1 had separate decomposition temperature between lubricant and other components. Prop2 had a single decomposition trend that is likely similar to OEM2.
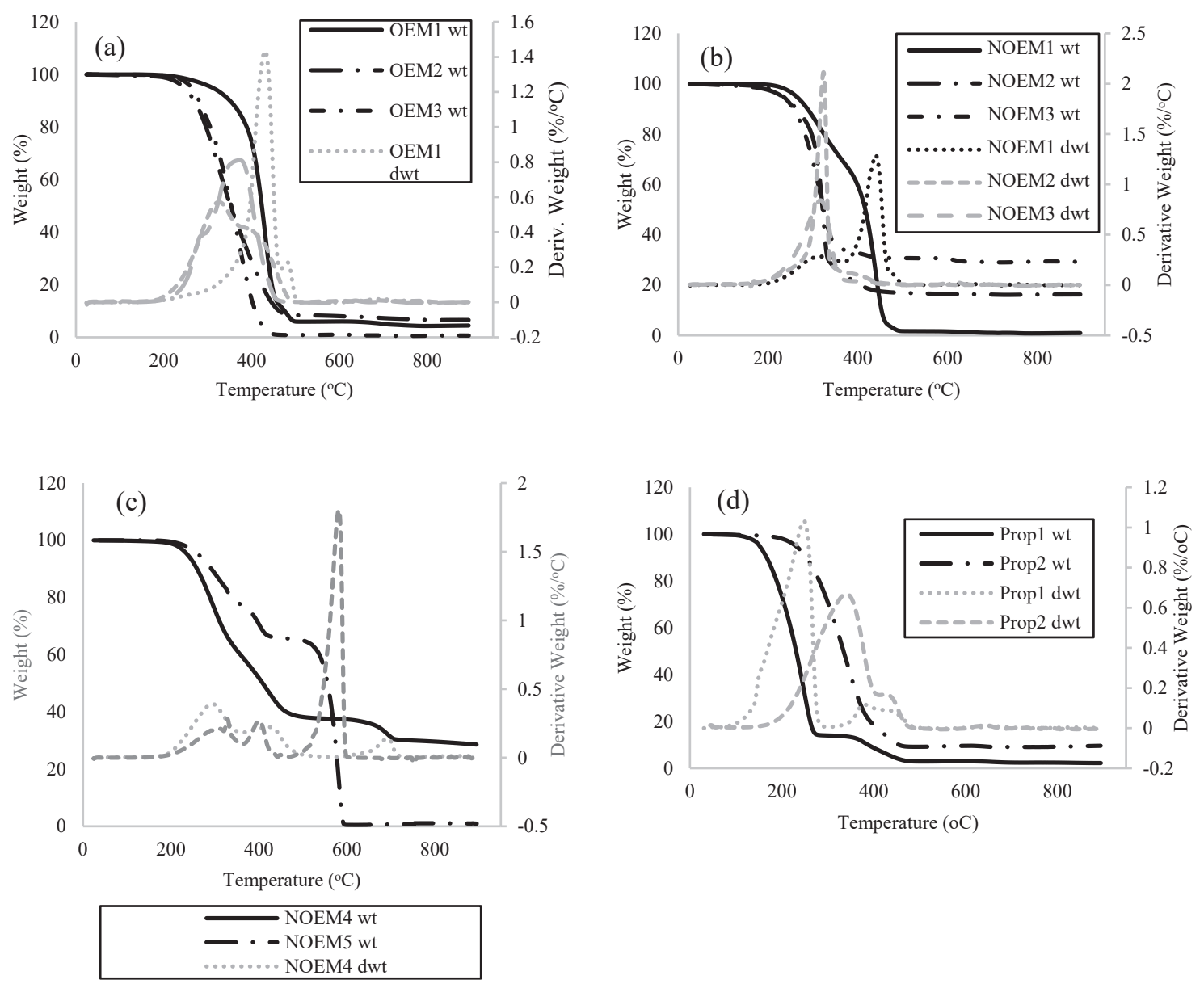

Fig. 6: TGA results indicating weight drop and derivative weight as the function of temperature.

Further study of heating at $10{ }^{\circ} \mathrm{C} /$ day is presented in Fig. 7. All sample weight data shows dropping trends similar to their weight drop in TGA results in Fig. 6, especially Prop1 
that dropped to $80 \mathrm{wt} \%$ after 10 days at $150{ }^{\circ} \mathrm{C}$. The drop greater than $20 \mathrm{wt} \%$ is not a stable grease [5].

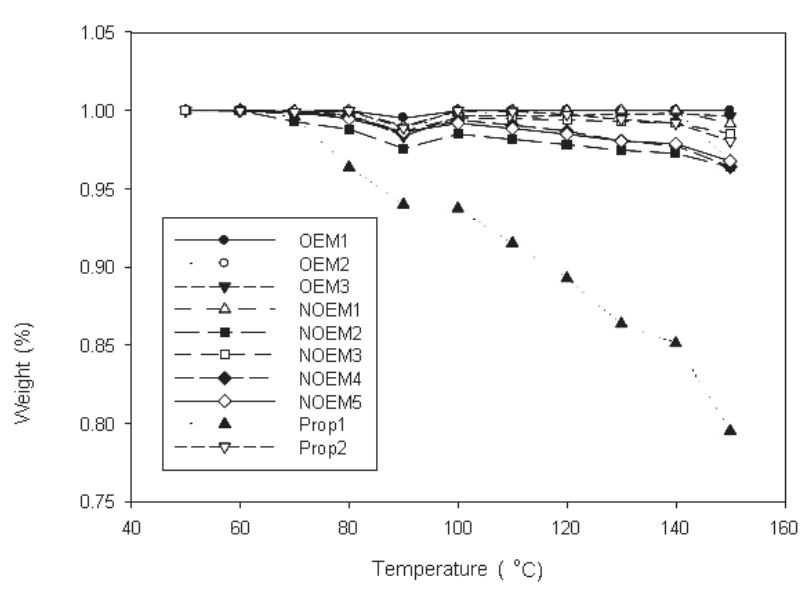

Fig. 7: Weight of grease sample after 10 days of heating at $10{ }^{\circ} \mathrm{C} /$ day.

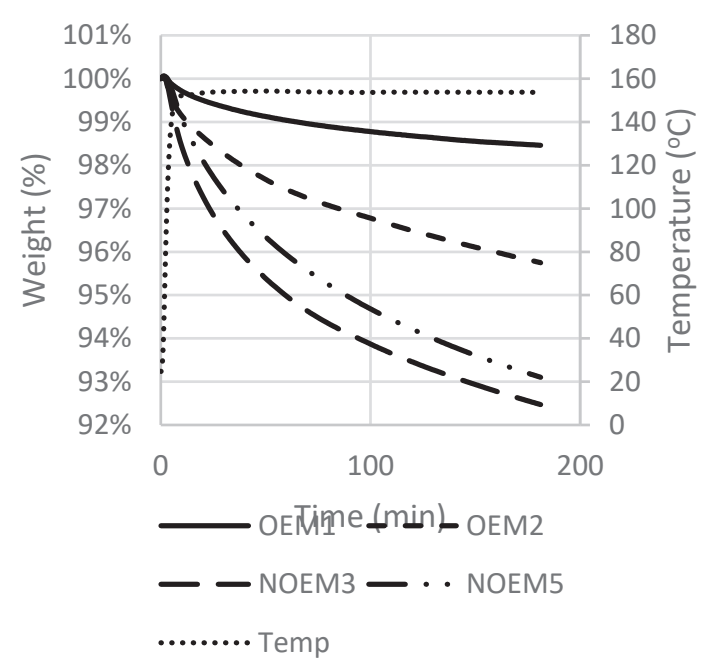

Fig. 8: Isothermal TGA of 4 samples.

Isothermal TGA analysis of selective samples at $150{ }^{\circ} \mathrm{C}$ in Fig. 8 reveals a trend of weight decrease that can be projected to estimate the final weight. The declination of sample weight can be expressed as exponential decay in Eq. (1) where the fitness for all data, $\mathrm{R}^{2}>$ $99 \%$, was significant. From the values of constants in Table 5, A denotes the final weight of the sample or residue at the infinity shows an excellent result, which is $98.4 \mathrm{wt} \%$. Nonrecommended greases also had fairly comparable results having residue greater than 90 $\mathrm{wt} \%$. The ageing of the grease is more apparent on the parameters that correspond to time. The rate of non-linear declination, or degradation, of the samples can be identified from multiplication of $\mathrm{B}$ and $\mathrm{C}$, which is the derivation constant of the exponential equation. OEM1 has the lowest rate and NOEM3 showed 5.6 times faster rate implying that NOEM3 might need to be replaced more frequently due to relatively fast decay. From this method of analysis, planning of grease replacement can be made when low performance grease is used.

$$
m=A+B \exp (-C t)
$$

Table 5: Parameters of exponential decay of sample weight.

\begin{tabular}{ccccc}
\hline Samples & $\begin{array}{c}\mathbf{A} \\
(\mathbf{w t} \%)\end{array}$ & $\begin{array}{c}\mathbf{B} \\
(\mathbf{w t} \%)\end{array}$ & $\begin{array}{c}\mathbf{C} \\
(\mathbf{m i n})\end{array}$ & $\begin{array}{c}\mathbf{B}^{*} \mathbf{C} \times \mathbf{1 0}^{4} \\
(\mathbf{w t} \% \mathbf{m i n})\end{array}$ \\
\hline OEM1 & 0.9839 & 0.0155 & 0.0144 & 2.23 \\
OEM2 & 0.9544 & 0.0423 & 0.0122 & 5.16 \\
NOEM3 & 0.9246 & 0.0719 & 0.0175 & 12.58 \\
NOEM5 & 0.9258 & 0.0735 & 0.0130 & 9.56 \\
\hline
\end{tabular}

Table 6 tabulates the results of the bleeding test and a comparison between fresh grease and the 10-day-heating grease. The circle area of stain, $\mathrm{S}$, and its change due to the heat treatment was calculated using Eqs. (2) and (3). OEM1 shows excellent consistency with difference of $39.81 \%$. The bleeding of OEM1 was not from molten grease as evidenced 
from the dropping point test. Other greases show negative values, which imply the potential of hardness of the grease increases. From the list of the grease samples OEM1 is therefore preferable.

$$
\begin{aligned}
& S=0.785\left(D^{2}-100\right) \\
& \% \text { Diff }=100\left(\frac{S \text { used }-S \text { fresh }}{S \text { fresh }}\right)
\end{aligned}
$$

Table 6: Circle area $\left(\mathrm{mm}^{2}\right)$ of oil from grease in the bleeding tests

\begin{tabular}{cccc}
\hline Grease & Fresh & 10-Day Heated & \% Diff \\
\hline OEM1 & 438.6 & 612.4 & 39.81 \\
OEM2 & 967.3 & 604.65 & -37.49 \\
OEM3 & 1005.9 & 785 & -21.96 \\
NOEM1 & 706.7 & 500.9 & -29.33 \\
NOEM2 & 717 & 589.3 & -17.81 \\
NOEM3 & 855.9 & 643.8 & -24.78 \\
NOEM4 & 1167.1 & 110.1 & -90.57 \\
NOEM5 & 733.7 & 301.4 & -58.92 \\
Prop1 & 1976.7 & 16.5 & -99.17 \\
Prop2 & 1035.2 & 910.8 & -12.02 \\
\hline
\end{tabular}

\section{CONCLUSION}

Analysis methods of electrical-switch-lubricating grease were the focus of this study. Grease samples from the local electric power distributor and our institution were analyzed to meet the requirement of switchgear grease. Unstiffened, conductive, inert, and unhazardous grease is desired for lubricating electricity connections at switchgears of middle voltage of $11 \mathrm{kV}$. Thermogravimetry, dropping point, burning, oil bleeding, penetration, resistivity, corrosivity, chromatography, mass spectrometry, and IR spectrometry were the analyses conducted to select the best one. OEM1 was identified as having excellent properties. It showed single dropping weight at temperatures greater than $200{ }^{\circ} \mathrm{C}$, a high dropping point, inflammable drop, consistent bleeding value, consistent grease property (NLGI reading), good conductivity without producing a metal oxide layer, no hazardous chemicals, and compatible metal elements. For all other grease, the consumer needs to manage usage and stocking, such as frequent replacement of grease according to the ageing prediction, wearing proper personal protective equipment (PPE), and obtaining work permits to face the possibility of grease or switching failure.

\section{ACKNOWLEDGEMENTS}

The authors would like to express their gratitude and appreciation for the financial support from the Ministry of Higher Education (MOHE), Malaysia for the Fundamental Research Grant Scheme (FRGS KPT - RDU160129, Reference Number: FRGS/1/2016/TK02/ UMP/03/2 entitled Rheological and Structural Characterization of Emulsified Modification Bitumen Synthesized from Industrial Wastes). The supports from the Faculty of Chemical and Natural Resources Engineering and Universiti Malaysia Pahang, Malaysia are also acknowledged. Special gratitude is additionally expressed to our collaboration from the government-linked-company, Tenaga Nasional Berhad via its research institute, TNB 
Research Sendirian Berhad on their sponsorship to this study under purchase order no. 20784104.

\section{REFERENCES}

[1] Lugt PM. (2016). Modern advancements in lubricating grease technology. Tribology International, 97:467-477.

[2] IEC, High-voltage switchgear and controlgear, in Part 1: Common specifications for alternating current switchgear and controlgear. (2017): International Electrotechnical Commision.

[3] Snyder CA, Mayotte D, Donahue CJ. (2006). Analysis of the Thickening Agents in Automotive Greases by GC-MS. Journal of Chemical Education, 83(6): 902.

[4] De Los Santos Valladares L, Salinas DH, Dominguez AB, Najarro DA, Khondaker SI, Mitrelias T, Barnes CHW, Aguiar JA, Majima Y. (2012). Crystallization and electrical resistivity of $\mathrm{Cu} 2 \mathrm{O}$ and $\mathrm{CuO}$ obtained by thermal oxidation of $\mathrm{Cu}$ thin films on $\mathrm{SiO}_{2} / \mathrm{Si}$ substrates. Thin Solid Films, 520(20): 6368-6374.

[5] El-Adly, R.A. and G.M. Turky (2018) Comparative study between prepared electrical grease and the imported one. Egyptian Journal of Petroleum, 27 (2):209-213.

[6] Chudnovsky B. (2008) Lubrication manual: Lubrication instructions for major manufacturers' medium voltage and low voltage circuit breakers, switches and switchgear. lubrication instructions for major manufacturers' medium voltage and low voltage circuit breakers, switches and switchgear, ed. 6. US: Square D Company.

[7] Crippin JB. (2015). Types of Fires, ed. M.M. Houck. Academic Press.

[8] Hurley S, Cann PM. (1999). IR Spectroscopic analysis of grease lubricant films in rolling contacts, in Tribology Series, Dowson D et al., Editors. Elsevier. pp. 589-600.

[9] Jiabao P, Yanhai C, Jinyong Y. (2015). Effect of heat treatment on the lubricating properties of lithium lubricating grease. RSC Advances, 5(72):58686-58693.

[10] Carre DJ, Bauer R, Fleischauer PD. (1982). Chemical analysis of hydrocarbon grease from spin bearing tests. ASLE Transactions, 26 (4): 475-480.

[11] Takahashi J, Kasahara K. (2013). Analysis of inorganic impurities in lubricating oils by ICPMS. Application Note. Agilent Technology URL: http://hpst.cz/sites/default/files/attachments/5991-3263en-analysis-inorganic-impuritieslubricating-oils-icp-ms.pdf as accessed on 28/3/2019.

[12] Zhang X, Granhaug O, Hall G. (2015). Data model for overheat prediction of mediumvoltage switchgear. in $23^{\text {rd }}$ International Conference on Electricity Distribution. Lyon: CIRED. 